\title{
A Complex Program of Striatal Gene Expression Induced by Dopaminergic Stimulation
}

\author{
Joshua D. Berke, ${ }^{1,2}$ Ronald F. Paletzki, ${ }^{3}$ Gabriel J. Aronson, ${ }^{3}$ Steven E. Hyman, ${ }^{1}$ and Charles R. Gerfen ${ }^{3}$ \\ ${ }^{1}$ Molecular Plasticity Section, National Institute of Neurological Disorders and Stroke, Bethesda, Maryland 20892, \\ 2 Program in Neuroscience, Harvard University, Boston, Massachusetts 02115, and ${ }^{3}$ Laboratory of Systems \\ Neuroscience, National Institute of Mental Health, Bethesda, Maryland 20892
}

Dopamine acting in the striatum is necessary for normal movement and motivation. Drugs that change striatal dopamine neurotransmission can have long-term effects on striatal physiology and behavior; these effects are thought to involve alterations in gene expression. Using the 6-hydroxydopamine lesion model of Parkinson's disease and differential display PCR, we have identified a set of more than 30 genes whose expression rapidly increases in response to stimulation of striatal dopamine $D_{1}$ receptors. The induced mRNAs include both novel and previously described genes, with diverse time courses of expression. Some genes are expressed at near-maximal levels within $30 \mathrm{~min}$, whereas others show no substantial induction until $2 \mathrm{hr}$ or more after stimulation. Some of the induced genes, such as CREM, CHOP, and MAP kinase phosphatase-1, may

The mesostriatal dopamine system plays a key role in normal motor function (Albin et al., 1989) and associative learning (Schultz et al., 1997). Destruction of midbrain dopamine cells causes Parkinson's disease, and long-term dopamine replacement therapy with L-DOPA is associated with dyskinesias, hallucinations, and fluctuations in therapeutic response (Chase et al., 1993). The use of dopamine antagonists as antipsychotics can result in tardive dyskinesia, while drugs such as cocaine that increase striatal dopamine release can cause dependency and addiction (for review, see Hyman, 1996).

Many of the persistent consequences of dopaminergic drugs appear to result from changes in striatal physiology, including altered sensitivity to neurotransmitters. For example, cocaine administration leads to altered responsiveness of striatal medium spiny neurons to dopamine (Henry and White, 1991). Dopaminergic drugs rapidly cause changes in gene expression in striatal neurons (Robertson et al., 1989; Dragunow et al., 1990; Graybiel et al., 1990); these gene expression changes may be responsible for the alterations in striatal physiology. One example is dynorphin gene expression, which is progressively induced in dorsal striatum by cocaine. This may be a compensatory adaptation contributing to the aversive aspects of withdrawal by decreasing

Received March 23, 1998; revised May 4, 1998; accepted May 7, 1998.

This work was supported by the Intramural Programs of the National Institute of Mental Health and the National Institute of Neurological Disorders and Stroke. We thank Alex Cummins, Ron Harbaugh, Jim Nagle, Erica Olsen, and Erin Perry for technical assistance.

Correspondence should be addressed to Joshua Berke, National Institute of Neurological Disorders and Stroke, 36/4C-24, 36 Convent Drive, Bethesda, MD 20892-4135.

Copyright (ㄷ) 1998 Society for Neuroscience $\quad 0270-6474 / 98 / 185301-10 \$ 05.00 / 0$ be components of a homeostatic response to excessive stimulation. Others may be part of a genetic program involved in cellular and synaptic plasticity. A very similar set of genes is induced in unlesioned animals by administration of the psychostimulant cocaine or the antipsychotic eticlopride, although in distinct striatal cell populations. In contrast to some previously described early genes, most of the novel genes are not induced in cortex by apomorphine, indicating specificity of induction. Thus we have identified novel components of a complex, coordinated genetic program that is induced in striatal cells in response to various dopaminergic manipulations.

Key words: dopamine; striatum; CREB; differential display PCR; immediate-early genes; neuronal plasticity; addiction dopamine release (Steiner and Gerfen, 1993; Cole et al., 1995; Shippenberg and Rea, 1997).

Dopamine acts in the striatum through the $\mathrm{D}_{1}$ and $\mathrm{D}_{2}$ subfamilies of G-protein-coupled receptors. $D_{1}$ receptors are coupled to $\mathrm{G}_{\mathrm{S}} / \mathrm{G}_{\mathrm{olf}}$ and increase cAMP production, whereas $\mathrm{D}_{2}$ receptors are coupled to $G_{i} / G_{o}$ and decrease cAMP. $D_{1}$ receptor activation appears to be necessary for striatal gene induction by cocaine or L-DOPA (Young et al., 1991; Morelli et al., 1993; Steiner and Gerfen, 1995). This induction occurs selectively in the $40-50 \%$ of striatal neurons whose dopamine receptors are predominantly of the $\mathrm{D}_{1}$ type and project to the substantia nigra pars reticulata (Gerfen et al., 1990, 1995; Robertson et al., 1990). Increased cAMP can activate protein kinase $\mathrm{A}$, which phosphorylates the transcription factor cAMP response element-binding protein (CREB). $D_{1}$ stimulation of striatal cells also appears to cause changes in CREB phosphorylation and c-fos expression by increasing intracellular calcium, entering through either voltagesensitive calcium channels or NMDA receptors (Keefe and Gerfen, 1996; Konradi et al., 1996).

To gain a more complete picture of dopamine-related changes in striatal gene expression, we used differential display PCR (DDPCR). We took advantage of the rat 6-hydroxydopamine lesion model of Parkinson's disease, because the dopamine supersensitive state shows very robust CREB phosphorylation and induction of gene expression response after $\mathrm{D}_{1}$ receptor stimulation (Robertson et al., 1989; Cole et al., 1994). The specificity of this model was increased further by giving a continuous infusion of a $\mathrm{D}_{2}$ agonist to diminish lesion-induced alterations in striatopallidal neurons (Gerfen et al., 1990). Gene expression was compared between the normal and 6-OHDA-lesioned striata of animals that were given either saline or a $\mathrm{D}_{1}$ agonist and killed 1 or 
$24 \mathrm{hr}$ later. In this paper we describe a large set of known and novel genes that are rapidly induced by $\mathrm{D}_{1}$ stimulation, compare their time courses of expression, and examine their responses to other drugs.

\section{MATERIALS AND METHODS}

Animals. For all experiments, male Sprague Dawley rats (Taconic, NY), weighing $\sim 200 \mathrm{gm}$, were used. Rats were housed in groups of three in a temperature-controlled room on a $12 \mathrm{hr}$ light/dark schedule, with free access to food and water.

Dopamine depletions. These were performed as described (Gerfen et al., 1995). Briefly, $16 \mu \mathrm{g}$ of 6-hydroxydopamine (in $2 \mu \mathrm{l}$ of $0.02 \%$ ascorbic acid) was infused into the right medial forebrain bundle/rostral substantia nigra at anteroposterior (AP) $+3.5 \mathrm{~mm}$, mediolateral $(\mathrm{ML})+1.5 \mathrm{~mm}$, dorsoventral (DV) $+2.0 \mathrm{~mm}$ (relative to interaural zero). Animals were then left for 3 weeks to allow time for dopamine receptor supersensitivity to develop. At 3 weeks after the lesion, animals used for differential display and initial in situ confirmation of differential expression were implanted with an osmotic pump (Alza Pharmaceuticals, Palo Alto, CA). The pump was filled with quinpirole, set to administer a dose of $1 \mathrm{mg} \cdot \mathrm{kg}^{-1} \cdot \mathrm{d}^{-1}$, and then implanted subcutaneously in the back. Animals were injected with saline or SKF38393 5 d later, without removing the osmotic pump.

Pharmacological treatments. Acute drug treatments were given intraperitoneally, dissolved in $0.02 \%$ ascorbic acid. All drugs were obtained from Sigma [(St. Louis, MO) cocaine HCl, 6-hydroxydopamine, apomorphine] or RBI [(Natick, MA) SKF38393, quinpirole, eticlopride].

$R N A$ isolation. Animals were killed with $\mathrm{CO}_{2}$ and decapitation. Brains were removed and rapidly chilled in ice-cold saline, and the striata were dissected out between approximately $+11 \mathrm{~mm}$ and $+9 \mathrm{~mm}$ AP [relative to intra-aural zero, using the atlas of Paxinos and Watson (1986)]. Tissue was frozen in tubes chilled on dry ice and stored at $-80^{\circ} \mathrm{C}$ and then homogenized using a Polytron (Kinematica/Brinkmann Instruments) in TriReagent with Microcarrier gel (Molecular Research) following the manufacturer's instructions. RNA was further purified by incubation with DNase I (Promega, Madison, WI) and phenol/chloroform, chloroform/isoamylalcohol extractions. After UV spectrophotometric quantitation, RNA integrity and quality were verified by running $1 \mu \mathrm{g}$ on a $1 \%$ native agarose gel.

Differential display RT-PCR. For each condition to be tested, striata from two separate animals were used for reverse transcription. RNA (2 $\mu \mathrm{g}$ ) was mixed with $0.5 \mu \mathrm{l}$ of RNAsin (Promega), $0.4 \mathrm{nmol}$ of dNTP (Boehringer Mannheim, Indianapolis, IN), $4 \mu$ l of Moloney Murine Leukemia Virus (MMLV) reverse transcriptase buffer (Promega), and 4 pmol of $3^{\prime}$ primer in $19 \mu \mathrm{l}$ of total volume. $3^{\prime}$ primers were "one-baseanchored" and of the form GGGCG AAGCT TTTTT TTTTT M, where $\mathrm{M}$ is $\mathrm{A}, \mathrm{C}$, or $\mathrm{G}$. These primers include a HindIII restriction site (Liang et al., 1994) and partial T7 polymerase sites. The reaction was heated at $65^{\circ} \mathrm{C}$ for $5 \mathrm{~min}$, and then at $37^{\circ} \mathrm{C}$ for $10 \mathrm{~min}$. MMLV reverse transcriptase ( $1 \mu \mathrm{l}$; Promega) was then added, and the reaction was left at $37^{\circ} \mathrm{C}$ for an additional $50 \mathrm{~min}$. Finally the reaction was heated to $95^{\circ} \mathrm{C}$ for $5 \mathrm{~min}$ and then placed on ice. Of this RT reaction, $1.1 \mu \mathrm{l}$ was mixed with $1.1 \mu \mathrm{l}$ of $10 \times$ PCR buffer (Boehringer Mannheim), $0.22 \mathrm{nmol}$ of dNTP, $2.2 \mathrm{pmol}$ of $3^{\prime}$ primer as above, $2.2 \mathrm{pmol}$ of $5^{\prime}$ primer, $0.14 \mu \mathrm{l}$ of ${ }^{33} \mathrm{P}$-dATP (catalog \#NEG612H; New England Nuclear, Boston, MA), and $0.11 \mu \mathrm{l}$ of Taq polymerase (Boehringer Mannheim) in a total volume of $11 \mu \mathrm{l} .5^{\prime}$ primers were of the form GACAC TATAG AATTC NNNNN NN, where $\mathrm{N}$ is any base. These primers include an EcoRI restriction site and a partial SP6 polymerase site. Thermal cycling was performed in an MJ Research PTC-200 96 V cycler under the following conditions (modified from Zhao et al., 1995): $94^{\circ} \mathrm{C}, 2 \mathrm{~min} ; 4$ cycles of $94^{\circ} \mathrm{C}, 15 \mathrm{sec}, 40^{\circ} \mathrm{C}, 4 \mathrm{~min}$, $72^{\circ} \mathrm{C}, 3 \mathrm{~min} ; 29$ cycles of $92^{\circ} \mathrm{C}, 15 \mathrm{sec}, 55^{\circ} \mathrm{C}, 1 \mathrm{~min}, 72^{\circ} \mathrm{C}, 1.5 \mathrm{~min}+3$ sec/cycle; $68^{\circ} \mathrm{C}$ for $5 \mathrm{~min} ; 4^{\circ} \mathrm{C}$, hold. To each PCR reaction $2.6 \mu \mathrm{l}$ of $5 \times$ DNA dye was added, and $1.5 \mu \mathrm{l}$ samples were loaded onto a $61 \mathrm{~cm}$ gel in a Genomyx-LR sequencer (Genomyx Corp., Foster City, CA). The gel was $340 \mu \mathrm{m}$ thick and was cast from 4.5\% HR-1000 gel (Genomyx). Gels were run for $16 \mathrm{hr}$ at $50^{\circ} \mathrm{C}, 1000 \mathrm{~V}, 100 \mathrm{~W}$, then dried onto the glass plate, washed, and exposed to Biomax-MR film (Eastman Kodak, Rochester, $\mathrm{NY}$ ) for 2-4 $\mathrm{d}$. Using this protocol we obtained a consistent band pattern ranging from $\sim 500 \mathrm{bp}$ to $\sim 2 \mathrm{~kb}$ in size. In most cases, a $100 \mathrm{bp}$ DNA ladder (Life Technologies, Gaithersburg, MD) was radioactively labeled and run alongside the DDPCR samples to allow accurate estimation of band size. In total, approximately 150 primer combinations were used for each of the four conditions (see Fig. 1); each primer combination produced several hundred bands.

Differentially expressed bands were excised from the gel and reamplified in the presence of $0.4 \mu \mathrm{l}$ of Expand High Fidelity polymerase mix (Boehringer Mannheim), $4 \mu \mathrm{l}$ of $10 \times \mathrm{HiFi}$ buffer 2 (Boehringer Mannheim), $1.6 \mathrm{nmol}$ of dNTP, and $16 \mathrm{pmol}$ of each reamp primers in a total volume of $40 \mu \mathrm{l}$. Reamp primers were CGCGC GTAAT ACGAC TCACT ATAGG GCGAA GCTTT TTTTT TTT, and CATAC GATTT AGGTG ACACT ATAGA ATTC. These complete the RNA polymerase sites on either side of the reamplified DDPCR band. Of this reaction, $32 \mu \mathrm{l}$ was mixed with $8 \mu \mathrm{l}$ of DNA dye and run out on a $1 \%$ agarose gel with ethidium bromide. Where a band of the predicted size was apparent, it was excised and purified using Qiaquick columns (Qiagen Inc., Valencia, CA) into $30 \mu \mathrm{l}$ of water, and $2 \mu \mathrm{l}$ was used as a template for in vitro transcription as described below. In situ hybridization was performed (see below) using tissue sections from animals treated in the same way as the DDPCR RNA samples. Genes whose differential expression was confirmed with in situ hybridization were cycle-sequenced, either directly using the reamp primers described above or by previous subcloning into pGEM-7z (Promega) or pCRII-TOPO (Invitrogen, Carlsbad, CA).

Sequence analysis. Sequence data were compared with GenBank at the National Library of Medicine, using the blastn algorithm on the "nr" nonredundant database, at their online website. In some cases (e.g., fosB), sequences gave no match to rat sequences but extremely close matches to known mouse sequences; these were assumed to be the rat homologs of the mouse genes. Sequences that gave no matches were designated as novel sequences. In one case (ania-7) the sequence of the DDPCR fragment contained a repeat sequence found in many genes. In this instance, oligo probes were designed to the unique portion of the sequence and used to reconfirm differential expression. Novel sequences were further compared with the GenBank dbEST database. We found that ania- 6 and ania-11 each had several close matches to mouse and human expressed sequence tags; the others did not. All novel gene fragments presented in this paper were subcloned, and the in situ hybridization shown uses probes from individual, sequenced colonies. Sequences were submitted to GenBank under the following accession numbers: ania1-6, AF030086-91; ania7-12, AF050659-64.

Generation of probe templates for known genes. For most of the known genes tested, $450-1000$ bp templates were obtained by PCR amplification from rat cDNA (Clontech, Palo Alto, CA, or Life Technologies), followed by subcloning into pCRII-TOPO and sequencing to confirm identity. In some cases, 45-50 mer oligo probes were designed from GenBank sequences (c-jun: GGTCG CAACC CAGTC CATCT TGTGT ACCCT TGGCT TCAGT ACTCG GACAC; junB: ACTGG GCGCA GGCGG GCAGG CCAGA GTCCA GTGTG TGAGC TGCGC C; COX-2: GAACA TCACG GGCTC CGCCA CCTTC CTACG CCAGC AATCT GACGT; nur77: GTGGT CACGC GGTCC TGGGC TCGTT GCTGG TGTTC CATAT TGAGC) and checked with blastn as above to avoid cross-hybridization. In all cases oligonucleotides were from Life Technologies. GenBank accession numbers used to design probes were as follows: arc U19866; egr-3 U12428; narp S82649; rheb U08227; fra-2 U18982; tPA M31197; c-fos X06769; nur77 U17254; c-jun X12761; junB X54686; junD D26307; COX-2 S67722.

Probe labeling and in situ hybridization. Procedures were as described in Gerfen et al. (1995). Briefly, RNA probes were produced by in vitro transcription using SP6 or T7 polymerases, in the presence of 35-S-UTP (New England Nuclear) or digoxygenin (Boehringer Mannheim). Oligonucleotide probes were end-labeled using terminal deoxynucleotidyl transferase (Boehringer Mannheim) and ${ }^{35} S$-dATP (New England Nuclear). ${ }^{35} \mathrm{~S}$-labeled probes were hybridized overnight either singly or in combination with digoxygenin-labeled enkephalin or $D_{1}$ receptor probes. Each slide had three $12 \mu \mathrm{m}$ coronal tissue sections from rostral, middle, and caudal striatum $(\sim 10.7,9.2$, and $8.0 \mathrm{~mm}$ anterior to the interaural line). After washing, digoxygenin label was detected using alkaline phosphatase-conjugated Fab fragment (Boehringer Mannheim) and visualized with nitroblue tetrazolium and 5-bromo-4-chloro-3-indolyl phosphate toluidine salts. Slides were placed on Biomax MR film (Kodak) and allowed to expose for 3-30 d. Slides were then dipped in emulsion (Amersham or Kodak), exposed for 1-3 months, and developed using standard darkroom techniques.

Image analysis. Images were captured from film using a light table and CCD camera, together with National Institutes of Health Image software (W. Rasband, National Institute of Mental Health). For quantitation of gene induction, average gray values from an area of dorsal striatum of 


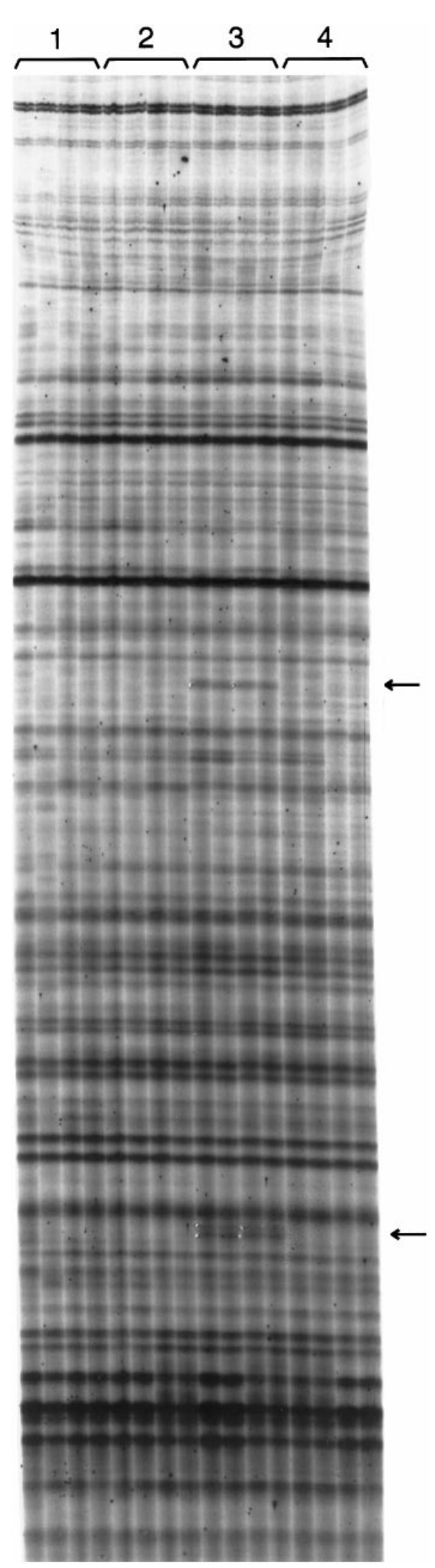

Figure 1. A fragment of a typical differential display film. This portion of the film has an approximate size range of $600-1500 \mathrm{bp}$ and is $30 \mathrm{~cm}$ long. The conditions used in the screen are as follows. Conditions 1 and 2 are the unlesioned (left) and lesioned (right) striata, respectively, from animals given saline injections and killed $1 \mathrm{hr}$ later. Conditions 3 and 4 are fixed size were measured on both rostral and middle striatal sections and averaged. For each section, the average gray value of a portion of overlying white matter (corpus callosum) was subtracted, as background correction.

\section{RESULTS}

We obtained RNA for DDPCR from rats treated in the following manner. First we performed unilateral 6-hydroxydopamine lesions, causing destruction of the nigrostriatal dopamine pathway. To further isolate a $\mathrm{D}_{1}$-supersensitive response, 3 weeks after the lesion we implanted a subcutaneous osmotic pump that continuously supplied quinpirole, a $D_{2}$ agonist $\left(1 \mathrm{mg} \cdot \mathrm{kg}^{-1} \cdot \mathrm{d}^{-1}\right)$. Five days later the animals were given injections of either saline or SKF38393 (5 mg/kg, i.p.), a selective $\mathrm{D}_{1}$ agonist. As shown in Figure 1, we compared the unlesioned and lesioned striata of saline-injected animals with striata from lesioned animals given SKF38393 and killed $1 \mathrm{hr}$ and $24 \mathrm{hr}$ later.

The great majority of the differentially expressed genes we observed showed acute, but not persistent, upregulation after $\mathrm{D}_{1}$ stimulation. Some examples are shown in Figure 1. This rapidly induced yet transient genetic response is the subject of the rest of this paper.

\section{Identification of $D_{1}$-induced genes}

More than 30 genes are rapidly induced by selective $\mathrm{D}_{1}$ stimulation in the supersensitive rat striatum. Some examples are shown in Figure 2. Of the genes found in the screen, some (e.g., zif 268) were expected because of previous studies; others (e.g., CHOP) are known genes not previously known to be regulated under these circumstances, and others have no matching sequences in GenBank. Two other novel gene fragments had consistent but weak inductions and are not shown. In parallel with the differential display screen, we also examined the expression pattern of a number of genes whose induction was either expected because of previous work or had been described as immediate-early genes in brain under other conditions. Some of these are shown in Figure 2.

To confirm that these genes are indeed being induced in $D_{1}$ receptor-bearing striatonigral neurons, in some cases we performed double-label in situ hybridization. As an example, Figure 3 shows that the novel gene ania-4 is selectively induced in cells expressing the $D_{1}$ receptor but not enkephalin (a marker of striatopallidal neurons). All the genes we have so far examined in this way (including arc, $c$-fos, zif 268, ania-1, ania-3, ania-4, and ania-6; data not shown) have also shown selective induction in $\mathrm{D}_{1}$-receptor-expressing cells after SKF38393.

\section{Time courses of gene induction}

As an initial functional comparison of the many induced genes, we examined in detail their time course of induction after $D_{1}$ stimulation in the lesioned striatum. Although most induced genes show maximal induction $\sim 2 \mathrm{hr}$ after stimulation, overall they show striking differences in time course; some examples are illustrated in Figure 4A. Some genes, such as $c$-fos and ania-5, are

\section{$\leftarrow$}

the lesioned striata from animals given SKF38393 (5 mg/ $\mathrm{kg}$ ) and killed after 1 and $24 \mathrm{hr}$, respectively. For each condition we used RNA from two different animals for reverse transcription, and each reverse transcription reaction was used for two duplicate PCR reactions, for a total of four lanes per condition for each primer combination. Arrows mark examples of differentially expressed bands; the white spots at the edge of these bands are pinholes used to orient the film over the dried gel for band excision. The upper of the two arrows indicates an 850 bp fragment of ania-6 mRNA. 


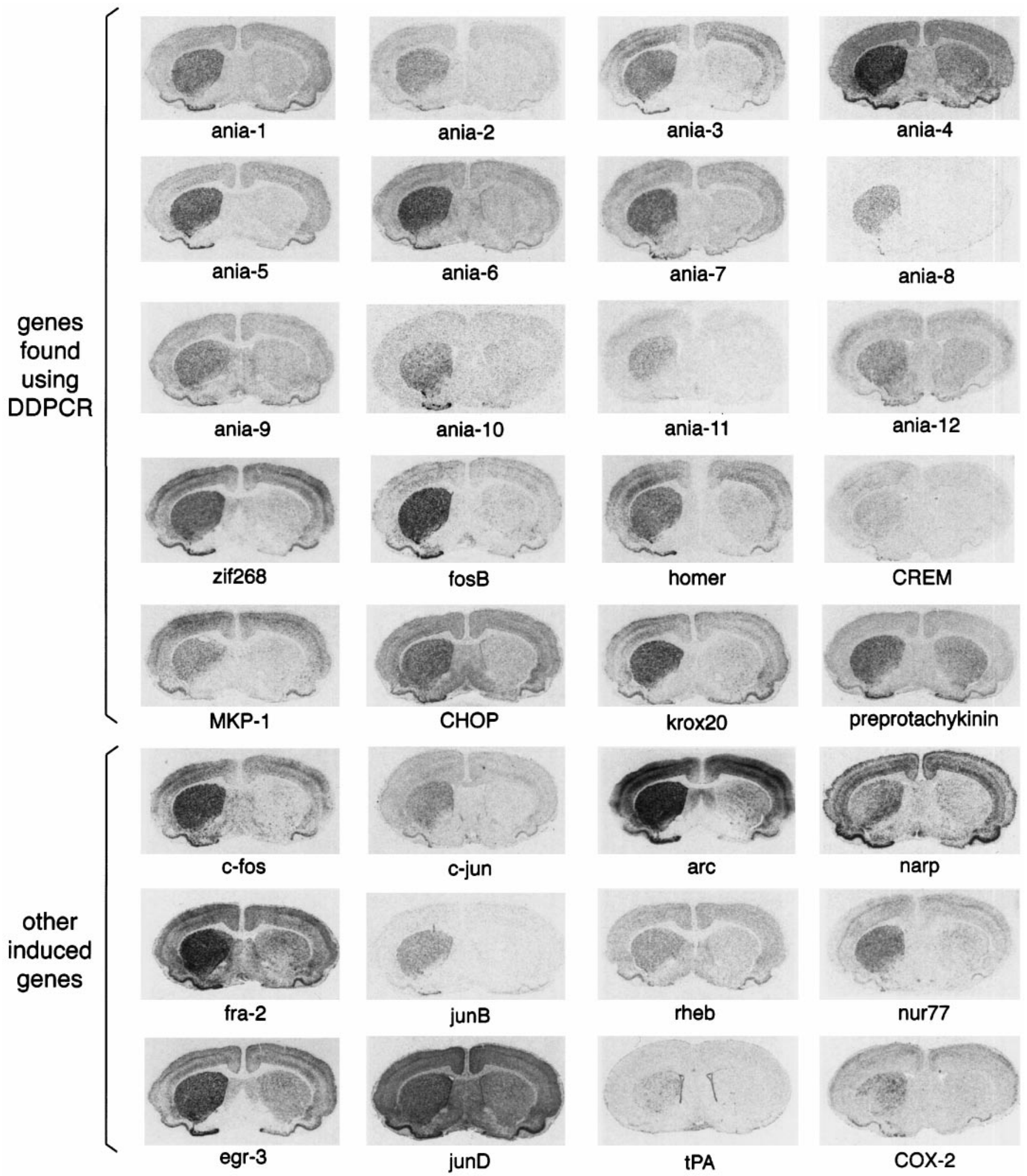

Figure 2. Examples of genes acutely induced by SKF38393. Each image is of a coronal rat brain section through the middle striatum, after in situ hybridization with a probe to the gene indicated. All of the brain sections are from animals given unilateral 6-hydroxydopamine lesions and then injected with SKF38393 $(5 \mathrm{mg} / \mathrm{kg}$ ) and killed $2 \mathrm{hr}$ later (except $t P A$, shown at $4 \mathrm{hr}$ after SKF38393). The lesioned side is shown on the left in each case. The genes designated "ania-1," "ania-2," etc., have no named matches in GenBank. Genes were designated as previously known on the basis of matches to the following accession numbers: homer U92079; CHOP (= GADD153) U36994; krox20 (= egr-2) U78102; preprotachykinin M34184; CREM M60285; fosB X14897; zif 268 (= NGFIA/egr-1) M18416; MKP-1 (= CL100) S81478. 


\section{A. Double label: ania-4 (sllver grains), D1 receptor (black)}

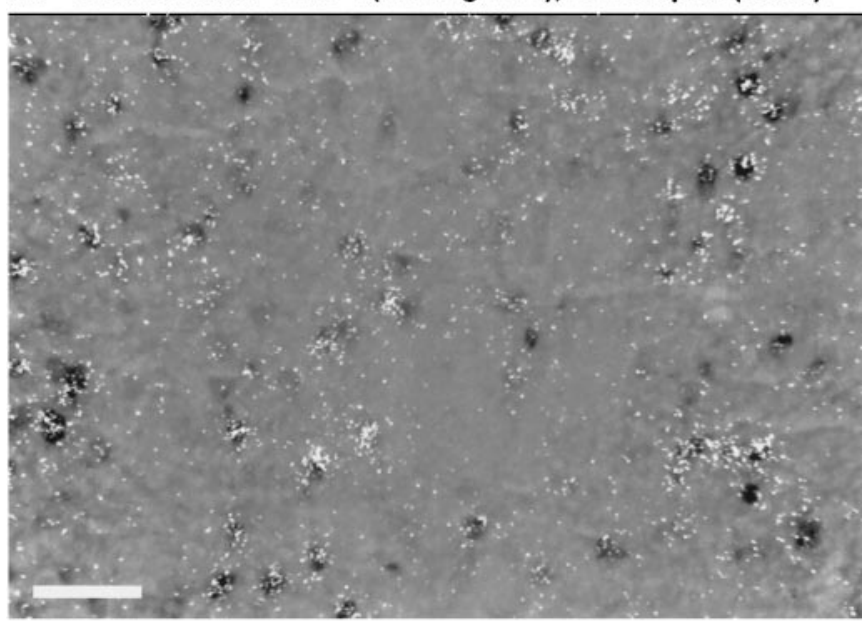

B. Double label: anla-4 (silver grains), enkephalin (black)

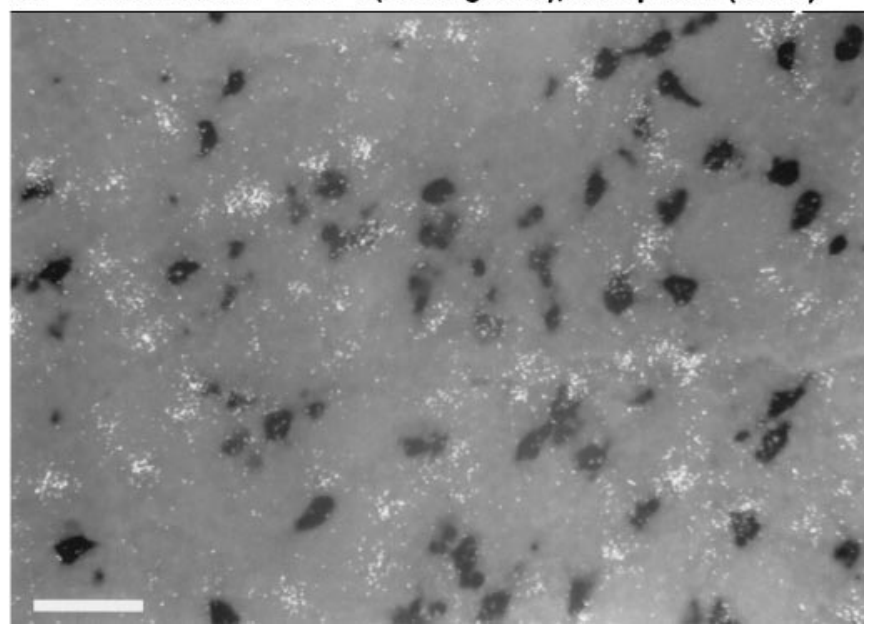

Figure 3. Selective gene induction in $\mathrm{D}_{1}$-receptor-bearing striatal neurons. Double-label in situ hybridization was performed with probes to the gene ania-4 (silver grains) and either $\mathrm{D}_{1}$ receptor $(A)$ or enkephalin $(B)$. The field in each case is taken from a brain section treated as in Figure 2 (i.e., $2 \mathrm{hr}$ after SKF38393, $5 \mathrm{mg} / \mathrm{kg}$ ), with additional hybridizations using digoxygenin-labeled probes, visualized by a dark reaction product. $A$, Induced ania- 4 mRNA colocalizes with $\mathrm{D}_{1}$ receptor mRNA. $B$, Induced ania-4 mRNA does not colocalize with mRNA for enkephalin, a marker of $\mathrm{D}_{2}$-receptor-bearing striatopallidal neurons. Scale bars, $\sim 50 \mu \mathrm{m}$.

highly upregulated within $30 \mathrm{~min}$, whereas others, such as ania-4 and ania-6, take $2 \mathrm{hr}$ to show substantial increases. After they reach peak induction, mRNAs can either be rapidly degraded or show persistent expression (compare ania-4, ania-6). Figure $4 B$ shows the quantitation of the images in Figure $4 A$, measuring the optical density from the dorsal striatum for four animals per time point. Although $\mathrm{D}_{1}$-receptor-expressing cells throughout the striatum can respond with this diverse set of genes, there are regional differences in the time course of expression. Most genes appear to be induced more rapidly in ventral striatum and persist longer in dorsal striatum.

In Figure $5 A$ we show quantifications for the time course of expression of other genes. The figure is roughly organized so that more rapidly induced genes are on the left of more slowly induced genes, and genes with a relatively prolonged induction are below those with a more rapid decay rate. A number of genes, such as ania-5, ania-7, ania- 8 , and krox-20, show an apparent dip at the 1 hr time point. Note that the dip in ania-5 was seen in two separate experiments, each with four animals per time point (Figs. 4B, 5) and is statistically significant (one-tailed $t$ tests, $p<0.001$, comparing $1 \mathrm{hr}$ time point with 0.5 and $2 \mathrm{hr}$ time points). All of the mRNAs that show a dip at $1 \mathrm{hr}$ appear to be rapidly degraded (Fig. 5A). The dip therefore may be the result of transient desensitization of the $\mathrm{D}_{1}$ signaling pathway, in combination with rapid mRNA degradation.

Other genes, such as narp and preprodynorphin, take longer to reach peak induction; these are shown in Figure $5 B$. All genes investigated return close to baseline within $24 \mathrm{hr}$, including ania-4, egr-3, rheb, narp, and preprotachykinin (data not shown).

\section{Gene induction after other dopaminergic manipulations}

Many classes of drugs can cause changes in striatal gene expression. To what extent are these different pharmacological stimuli engaging a similar genetic program? We examined the profile of gene expression $1 \mathrm{hr}$ after injecting cocaine, apomorphine, or eticlopride. The psychostimulant cocaine blocks presynaptic dopamine, norepinephrine, and serotonin reuptake transporters, causing prolonged availability of these neurotransmitters in the synaptic space. Apomorphine is a mixed $\mathrm{D}_{1} / \mathrm{D}_{2}$ agonist, and eticlopride is a $D_{2}$ antagonist with antipsychotic properties. Inductions in response to these drugs are bilateral. The animals were not previously given 6-OHDA lesions or any other treatment. Figure 5 shows some examples. Of the genes we tested with a strong striatal response to SKF38393, all also showed a strong striatal response to cocaine and eticlopride, with cocaine consistently producing a more medial induction pattern in the striatum than eticlopride.

The striatal cells responding to cocaine in each case are presumed to be $\mathrm{D}_{1}$-receptor-bearing striatonigral cells (Ruskin and Marshall, 1994; Steiner and Gerfen, 1995), whereas those responding to eticlopride are presumed to be $\mathrm{D}_{2}$-receptor-bearing striatopallidal cells (Robertson et al., 1992). We performed double-label in situ hybridization on tissue sections of eticloprideor cocaine-treated animals and confirmed that the novel gene ania-1 is induced in the expected cells (data not shown). It appears that cocaine and eticlopride can induce highly similar genetic programs in distinct cellular populations.

Different brain areas may have distinct sets of inducible genes. Apomorphine, like other dopamine agonists, causes a relatively modest induction of gene expression in the striatum of normal (unlesioned) animals; however, it can cause considerable gene induction in the cortex. Figure 6 shows that most of the novel genes we have found using striatum as source material show little cortical response to apomorphine, compared with c-fos, another previously described early gene, MAP kinase phosphatase-1 (MKP-1; also called CL100), and the novel gene ania-3.

\section{DISCUSSION}

\section{A complex set of dopamine-induced genes}

We wished to find genes whose expression was potentially responsible for the altered cellular and behavioral responses observed after exposure to dopaminergic drugs. We chose to use $D_{1}$ stimulation in unilaterally 6-OHDA-lesioned rats because this model gives very robust gene expression, allows direct side-to-side comparison within each animal, and is directly relevant to the clinical phenomenon of L-DOPA-induced dyskinesias. Using approximately 150 primer combinations, we found that more than 30 genes can be rapidly and transiently induced in this system; of 
A. c-fos

0

0.5

1

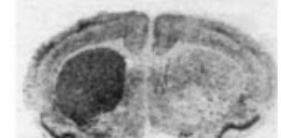

2

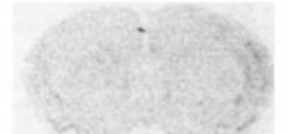

4

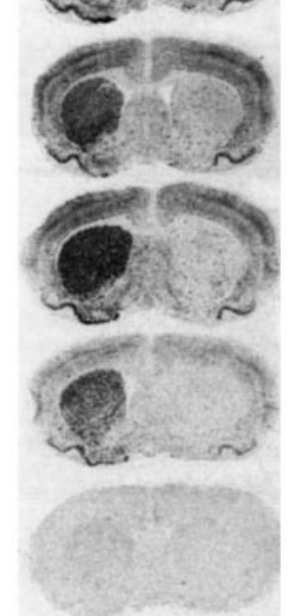

B.

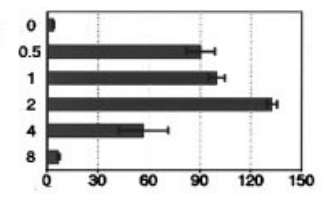

ania-5
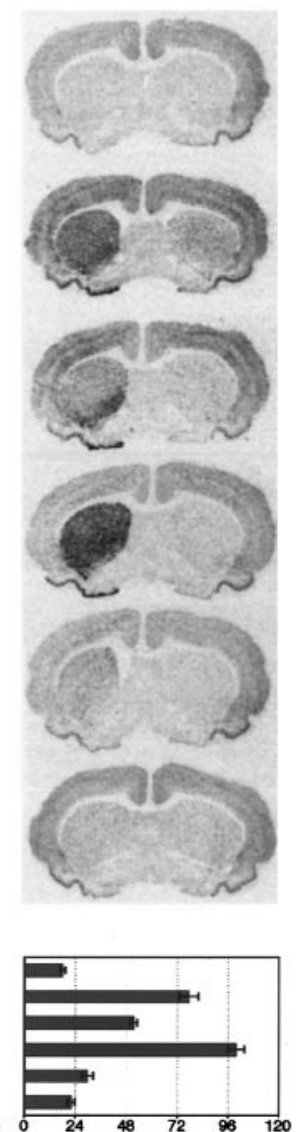

homer
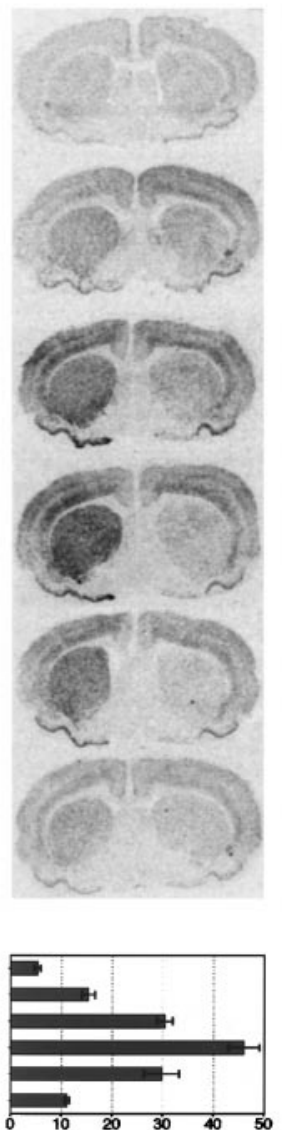

ania-6
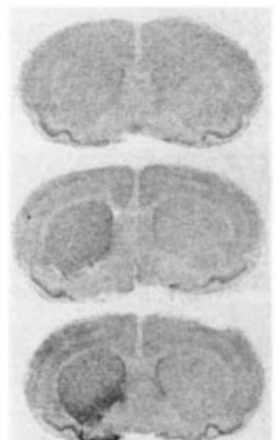

$\infty$
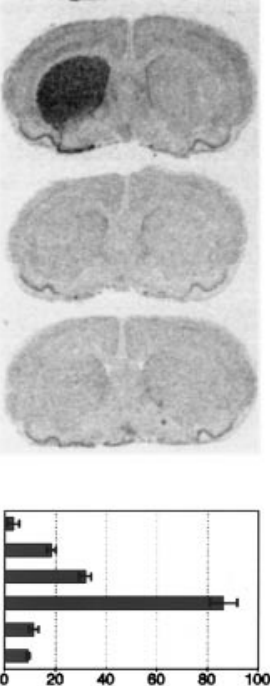

ania-4
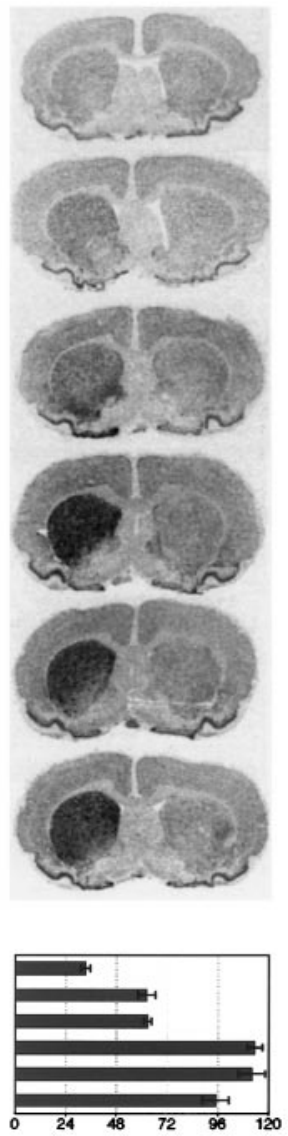

narp
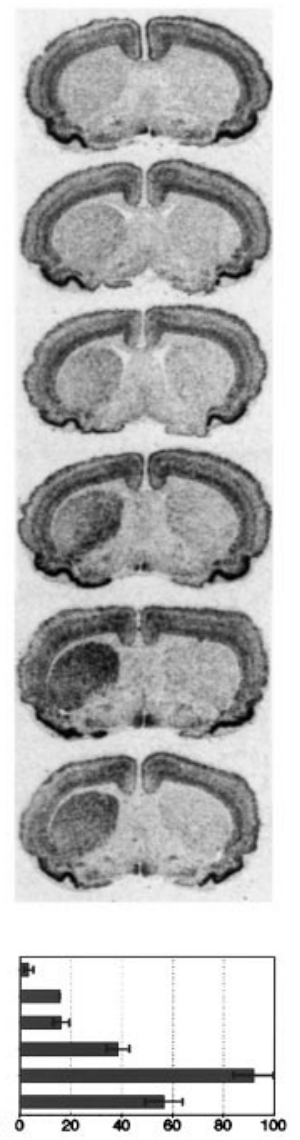

Figure 4. Five examples of distinct temporal patterns of gene expression after SKF38393 $(5 \mathrm{mg} / \mathrm{kg})$ given to 6-OHDA lesioned animals. Animals were killed at either $0,0.5,1,2,4$, or $8 \mathrm{hr}$ after injection of SKF38393, as indicated. $A$, Representative in situ hybridization images from each time point. Lesioned side is on the left as in Figure 2. B, Bar charts of average gray value measurements from the dorsal striatum. For each gene, sections from the same four animals were measured at each time point. The $x$-axis indicates average gray value, in arbitrary units. Error bars indicate SEM.

these, approximately half had not been described previously. Thus the striatal response to $\mathrm{D}_{1}$ stimulation involves a complex program of gene expression.

Because our DDPCR screen did not find all of the genes we know to be induced by dopamine, it is reasonable to assume that other novel genes remain to be found. Although it is difficult to estimate the total number of induced genes, we note that of the known genes we expected to find, about half appeared in the screen. This implies that the total number of inducible genes is probably more than 50 . One limitation of the present study is that the DDPCR screen only examined 1 and $24 \mathrm{hr}$ time points after $\mathrm{D}_{1}$ stimulation. There may be additional genes that show no detectable increase within the first hour but are subsequently induced and return to baseline within $24 \mathrm{hr}$. We note that the technique did display great sensitivity, detecting increases at the $1 \mathrm{hr}$ time point of a CREM gene and several novel genes that are barely visible with in situ hybridization. We did not observe any genes that are downregulated by $\mathrm{D}_{1}$ stimulation. We cannot be certain whether this is because of a limitation in our use of the DDPCR technique or whether it reflects the reality of few or no rapidly downregulated genes.

The 6-OHDA-lesioned striatum displays increased dopamine responsiveness compared with the unlesioned striatum, and this can be increased further by $\mathrm{D}_{1}$ stimulation (Juncos et al., 1989;
Morelli et al., 1989). Yet compared with the many genes induced within $1 \mathrm{hr}$ of dopamine stimulation, our DDPCR screen found very few genes with altered expression caused by 6-OHDA lesion alone or at $24 \mathrm{hr}$ after dopamine stimulation. It is possible that the altered dopamine sensitivity associated with these states is achieved through persistently altered expression of a small number of genes. Alternatively, it is possible that substantial changes in gene expression are not required.

\section{Induction time courses are diverse but transient}

We have demonstrated that a large number of striatal genes are rapidly induced by dopamine stimulation and return to baseline within $24 \mathrm{hr}$. The transience of this genetic response to dopamine is striking. It may be that a brief burst of gene upregulation is enough to alter cellular physiology, through persistent modification of proteins (Lisman and Goldring, 1988), through production of persistent proteins [such as chronic Fras (Hope et al., 1994)], or by causing structural changes such as alterations in cellular morphology or formation of new synapses (Robinson and Kolb, 1997). These types of explanation may account for the transient sensitivity to blockers of gene expression of late-phase hippocampal long-term potentiation [L-LTP (Nguyen et al., 1994)]. The set of genes necessary for L-LTP may overlap with those we have observed, because $D_{1}$ receptors have been directly implicated in 
A.
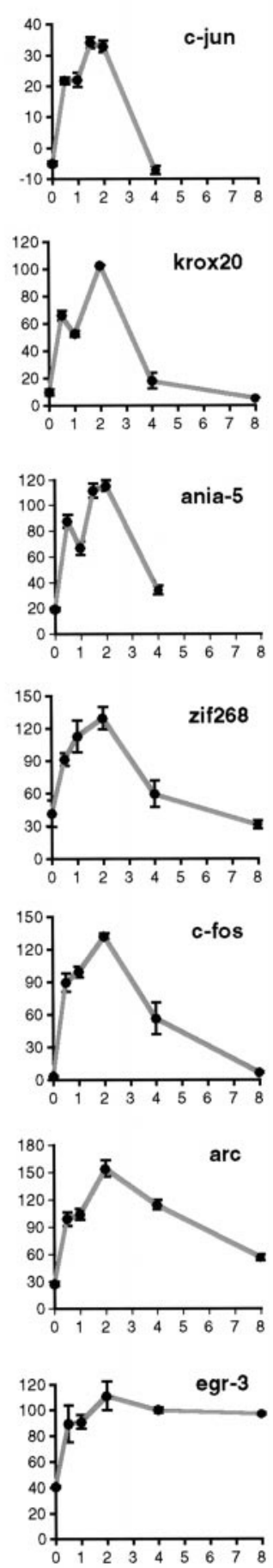
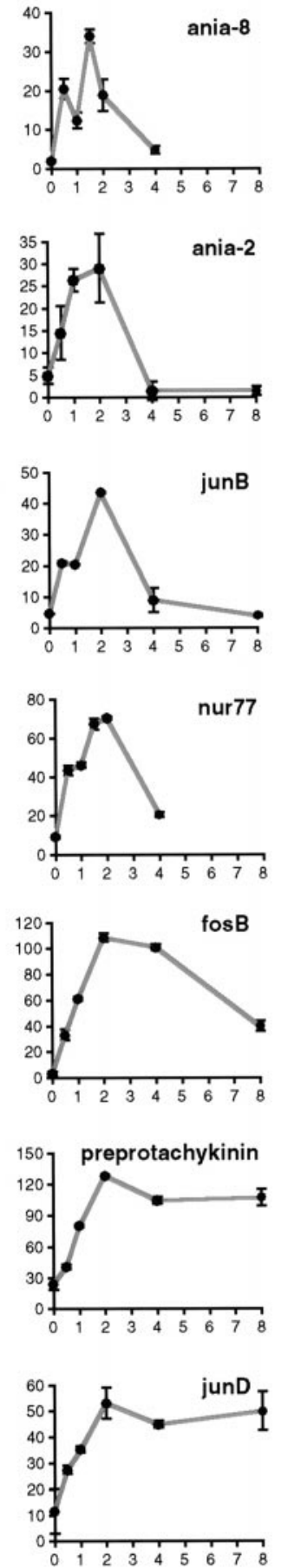
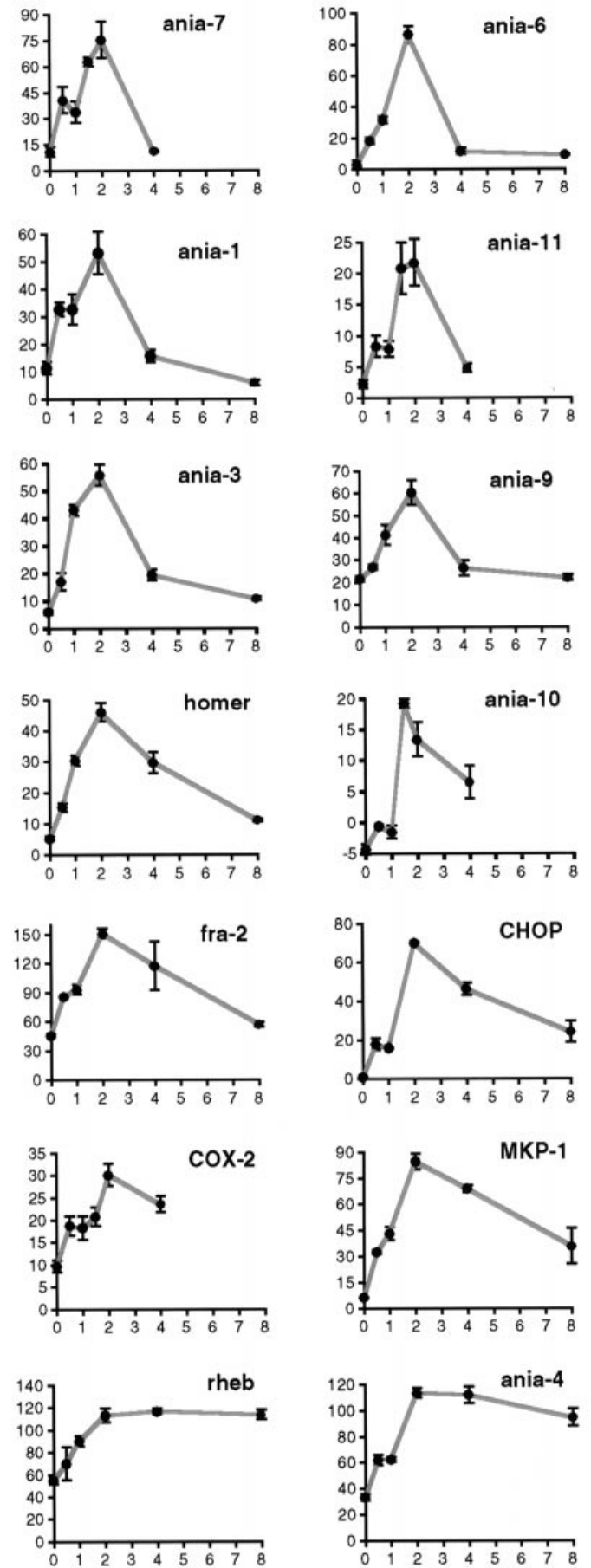

B.
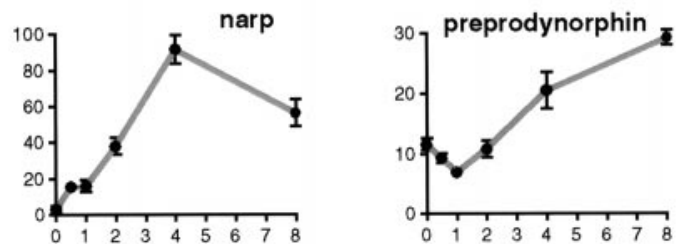

Figure 5. A, Time course examples for genes reaching peak induction within $2 \mathrm{hr}$. B, Preprodynorphin and narp take longer to reach peak induction. Graphs are quantitations from tissue sections at the same time points as in Figure 4, except for a few genes with rapid decay rates where data are shown from an experiment in which animals were killed at $0,0.5,1,1.5,2$, and $4 \mathrm{hr}$ after SKF38393 $(5 \mathrm{mg} / \mathrm{kg})$. The $y$-axis in each case is average gray value in dorsal striatum (in arbitrary units), and the $x$-axis is hours after SKF38393. In most cases $n=4$ animals per time point; for a few cases $n=2$ or 3. Error bars indicate SEM. Where no error bar is visible, the error was smaller than the graph symbol. 


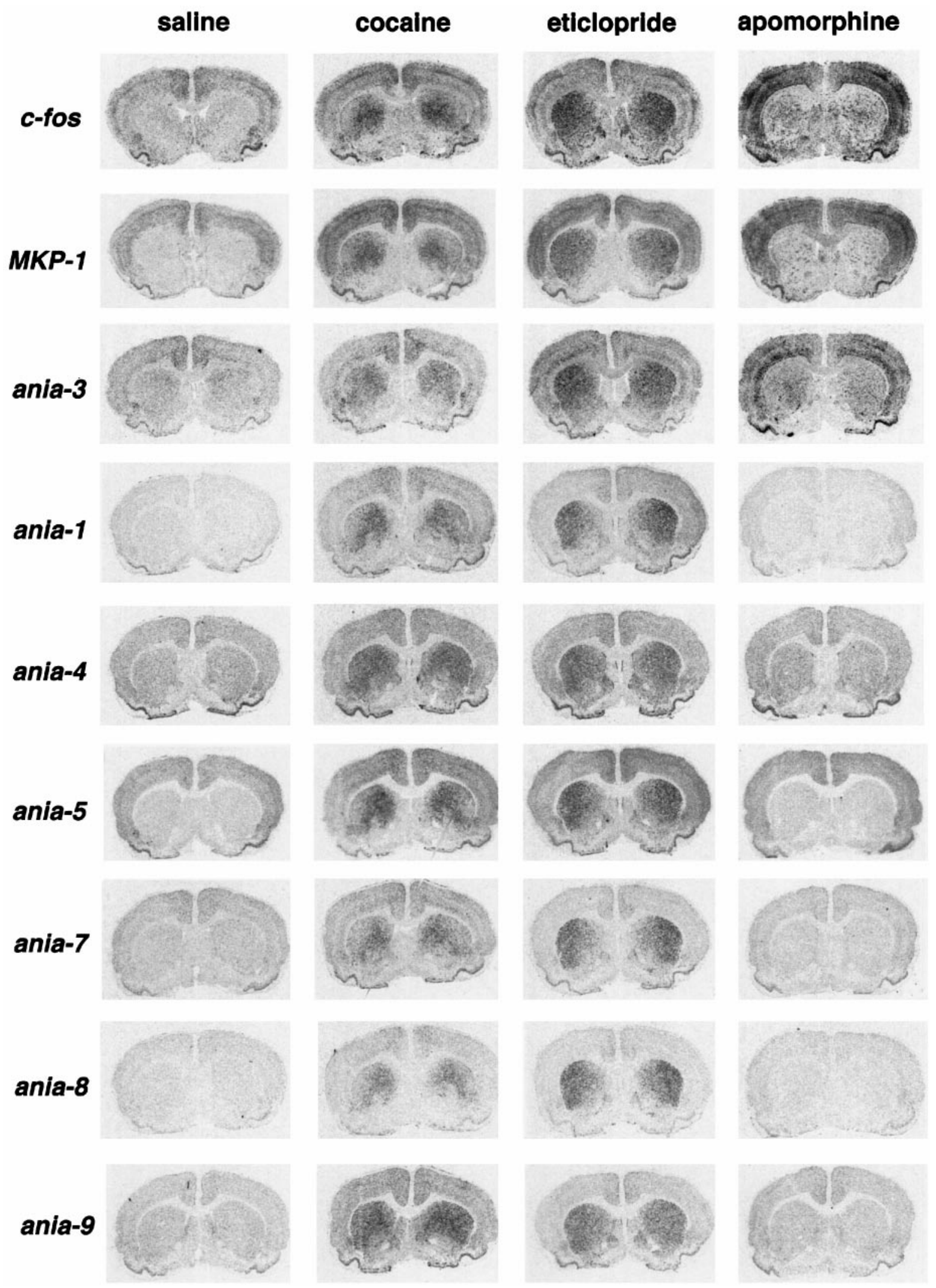

Figure 6. The striatal response to cocaine and eticlopride uses a similar set of genes. All brain sections shown are from normal (i.e., unlesioned) animals given the indicated drug and killed $1 \mathrm{hr}$ later. All drugs were given intraperitoneally at the following doses: cocaine $25 \mathrm{mg} / \mathrm{kg}$, apomorphine $2 \mathrm{mg} / \mathrm{kg}$, eticlopride $1 \mathrm{mg} / \mathrm{kg}$. 
hippocampal long-term potentiation (Frey et al., 1991; Huang and Kandel, 1995), and the cAMP/PKA/CREB pathway has been shown to be necessary for L-LTP and other memory models (for review, see DeZazzo and Tully, 1995). It has not yet been determined which genes downstream of CREB are critical for memory formation.

The large number of $\mathrm{D}_{1}$-induced striatal mRNAs do not form a single discrete wave of gene expression, but rather show great variation in both the rapidity with which they are induced and their relative persistence (Fig. $5 A, B$ ). Because many of the most rapidly induced genes are transcription factors, they may be regulating some of the later genes. It may be possible to learn more about specific genes by blocking transcription and/or translation at specific times after stimulation. We note, however, that a delay does not necessarily indicate dependence on new protein synthesis. Although both $c$-fos and dynorphin mRNAs are believed to respond to phosphorylation of CREB in striatum (Cole et al., 1995), c-fos is induced within $30 \mathrm{~min}$ after SKF38393, whereas dynorphin does not show substantial induction in the lesioned striatum until $\sim 4$ hr (Fig. $5 B$ ).

\section{A common genetic program induced by distinct drug classes}

Psychostimulants and antipsychotic drugs can lead to behavioral abnormalities both in humans and in animal models, including stereotypies and dyskinesias. Dyskinesias are also observed with the use of dopamine agonists in therapy for Parkinson's disease. We have observed that all of these treatments induce very similar sets of genes (Figs. 2, 6), despite quite different mechanisms of action. Although cocaine and $\mathrm{D}_{1}$ agonists are causing gene induction in striatonigral cells, and eticlopride is inducing genes in striatopallidal cells, the similarity of the induced genes suggests that similar adaptations are taking place in each case.

As with $\mathrm{D}_{1}$ agonists in the dopamine-depleted striatum, induction of $c$-fos by either psychostimulants or antipsychotics appears to require CREB (Konradi et al., 1994; Konradi and Heckers, 1995). The common induction of CREB in striatal neurons may account for the similar program of gene induction that we have observed. Other transcription factors may also be involved, because SKF38393 in lesioned striatum has been shown to increase AP-1 binding (Huang and Walters, 1996), as have psychostimulants and antipsychotics (Nguyen et al., 1992). This increase in AP-1 binding is consistent with the increases in fos and jun family member mRNAs. At the present time, however, there are no proven target genes that are upregulated in striatum by AP-1.

\section{Specificity of gene induction}

It is possible that the set of genes reported here merely represents a general neuronal response to strong stimulation. One reason to think that this is not the case is the variation in response to apomorphine. At the dose shown in Figure 6, a number of mRNAs are strongly induced in cortex, including c-fos, MKP-1, and ania-3. Others, including most of the novel genes reported here, do not show a substantial apomorphine response. Thus the expression of the set of genes discussed in this paper is not coupled in a fixed manner; i.e., they do not represent a common response to any stimulation that induces $c$-fos.

We note that most induced genes described previously in brain were initially found outside brain or in other brain regions such as hippocampus (Nedivi et al., 1993; Yamagata et al., 1993). The use of a striatum-based screen in the present study may account for the large number of novel genes found and their relative striatal specificity of induction.

\section{Genetic change and neuronal function}

The first genes known to show rapid induction in response to dopaminergic drugs were transcription factors, such as zif268, krox20, and members of the AP-1 family (Cole et al., 1992). These are presumably involved in regulating the expression of other genes. Over the last several years Worley and colleagues (Yamagata et al., 1994; Lyford et al., 1995; Tsui et al., 1996; Brakeman et al., 1997), using subtractive hybridization methods in seizure models, have uncovered genes (including arc, homer, narp, and rheb) that may have more direct effects on cellular physiology. At the present time we do not know the functions of the novel gene sequences (ania-1 through ania-12) reported here. Although it is possible that some of these novel sequences represent previously unreported parts of known genes, most of them do not show a spatial and temporal expression profile in common with the known genes we have studied. Our current efforts are directed toward discovery and manipulation of their corresponding full-length mRNAs.

Several of the induced genes may be acting as homeostatic responses to activation of signal transduction pathways. Among these are MKP-1 [also called CL100 (Takano et al., 1995)], which dephosphorylates MAP kinase, CREM, some forms of which are inhibitory versions of CREB (Stehle et al., 1993), and CHOP, which is an inhibitor/modulator of the transcription factor $\mathrm{C} / \mathrm{EBP}$ (Ron and Habener, 1992). The induction of the mRNAs for these genes potentially represents a compensatory response to activation of their cognate proteins. The MAP kinase and C/EBP pathways have been implicated in memory formation in other systems (Alberini et al., 1994; Martin et al., 1997). To our knowledge, no one has yet examined the role of MAP kinases or $\mathrm{C} / \mathrm{EBP}$ activation in dopamine-induced striatal gene induction.

Why do striatal cells respond to dopaminergic drugs with this diverse set of induced genes? There are several forms of neuronal adaptation taking place, including alterations in sensitivity to neurotransmitters and changes in membrane properties. The challenge is to relate these adaptations to specific changes in gene expression. We have shown that the sets of genes potentially involved is large. The task of sorting out the mechanisms by which they affect physiology will require extensive efforts by a number of laboratories.

\section{REFERENCES}

Alberini CM, Ghirardi M, Metz R, Kandel ER (1994) C/EBP is an immediate-early gene required for the consolidation of long-term facilitation in Aplysia. Cell 76:1099-1114.

Albin RL, Young AB, Penney JB (1989) The functional anatomy of basal ganglia disorders. Trends Neurosci 12:366-375.

Brakeman PR, Lanahan AA, O'Brien R, Roche K, Barnes CA, Huganir RL, Worley PF (1997) Homer: a protein that selectively binds metabotropic glutamate receptors. Nature 386:284-288.

Chase TN, Mouradian MM, Engber TM (1993) Motor response complications and the function of striatal efferent systems. Neurology 43:S23-27.

Cole AJ, Bhat RV, Patt C, Worley PF, Baraban JM (1992) D dopamine receptor activation of multiple transcription factor genes in rat striatum. J Neurochem 58:1420-1426.

Cole DG, Kobierski LA, Konradi C, Hyman SE (1994) 6-Hydroxydopamine lesions of rat substantia nigra up-regulate dopamine-induced phosphorylation of the cAMP-response elementbinding protein in striatal neurons. Proc Natl Acad Sci USA 91:9631-9635.

Cole RL, Konradi C, Douglass J, Hyman SE (1995) Neuronal adaptation to amphetamine and dopamine: molecular mechanisms of prodynorphin gene regulation in rat striatum. Neuron 14:813-823. 
DeZazzo J, Tully T (1995) Dissection of memory formation: from behavioral pharmacology to molecular genetics. Trends Neurosci 18:212-218.

Dragunow M, Robertson GS, Faull RL, Robertson HA, Jansen K (1990) $\mathrm{D}_{2}$ dopamine receptor antagonists induce fos and related proteins in rat striatal neurons. Neuroscience 37:287-294.

Frey U, Matthies H, Reymann KG, Matthies H (1991) The effect of dopaminergic $\mathrm{D}_{1}$ receptor blockade during tetanization on the expression of long-term potentiation in the rat CA1 region in vitro. Neurosci Lett 129:111-114.

Gerfen CR, Engber TM, Mahan LC, Susel Z, Chase TN, Monsma Jr FJ, Sibley DR (1990) $\mathrm{D}_{1}$ and $\mathrm{D}_{2}$ dopamine receptor-regulated gene expression of striatonigral and striatopallidal neurons. Science 250:1429-1432.

Gerfen CR, Keefe KA, Gauda EB (1995) $\mathrm{D}_{1}$ and $\mathrm{D}_{2}$ dopamine receptor function in the striatum: coactivation of $\mathrm{D}_{1^{-}}$and $\mathrm{D}_{2}$-dopamine receptors on separate populations of neurons results in potentiated immediate early gene response in $\mathrm{D}_{1}$-containing neurons. J Neurosci 15:8167-8176.

Graybiel AM, Moratalla R, Robertson HA (1990) Amphetamine and cocaine induce drug-specific activation of the c-fos gene in striosomematrix compartments and limbic subdivisions of the striatum. Proc Natl Acad Sci USA 87:6912-6916.

Henry DJ, White FJ (1991) Repeated cocaine administration causes persistent enhancement of $D_{1}$ dopamine receptor sensitivity within the rat nucleus accumbens. J Pharmacol Exp Ther 258:882-890.

Hope BT, Nye HE, Kelz MB, Self DW, Iadarola MJ, Nakabeppu Y, Duman RS, Nestler EJ (1994) Induction of a long-lasting AP-1 complex composed of altered Fos-like proteins in brain by chronic cocaine and other chronic treatments. Neuron 13:1235-1244.

Huang KX, Walters JR (1996) Dopaminergic regulation of AP-1 transcription factor DNA binding activity in rat striatum. Neuroscience 75:757-775.

Huang YY, Kandel ER (1995) $D_{1} / D_{5}$ receptor agonists induce a protein synthesis-dependent late potentiation in the CA1 region of the hippocampus. Proc Natl Acad Sci USA 92:2446-2450.

Hyman SE (1996) Addiction to cocaine and amphetamine. Neuron 16:901-904.

Juncos JL, Engber TM, Raisman R, Susel Z, Thibaut F, Ploska A, Agid Y, Chase TN (1989) Continuous and intermittent levodopa differentially affects basal ganglia function. Ann Neurol 25:473-478.

Keefe KA, Gerfen CR (1996) $D_{1}$ dopamine receptor-mediated induction of zif268 and c-fos in the dopamine-depleted striatum: differential regulation and independence from NMDA receptors. J Comp Neurol 367:165-176.

Konradi C, Heckers S (1995) Haloperidol-induced Fos expression in striatum is dependent upon transcription factor cyclic AMP response element binding protein. Neuroscience 65:1051-1061.

Konradi C, Cole RL, Heckers S, Hyman SE (1994) Amphetamine regulates gene expression in rat striatum via transcription factor CREB. J Neurosci 14:5623-5634.

Konradi C, Leveque JC, Hyman SE (1996) Amphetamine and dopamine-induced immediate early gene expression in striatal neurons depends on postsynaptic NMDA receptors and calcium. J Neurosci 16:4231-4239.

Liang P, Zhu W, Zhang X, Guo Z, O'Connell RP, Averboukh L, Wang F, Pardee AB (1994) Differential display using one-base anchored oligo-dT primers. Nucleic Acids Res 22:5763-5764.

Lisman JE, Goldring MA (1988) Feasibility of long-term storage of graded information by the $\mathrm{Ca} 2+$ /calmodulin-dependent protein kinase molecules of the postsynaptic density. Proc Natl Acad Sci USA 85:5320-5324.

Lyford GL, Yamagata K, Kaufmann WE, Barnes CA, Sanders LK, Copeland NG, Gilbert DJ, Jenkins NA, Lanahan AA, Worley PF (1995) Arc, a growth factor and activity-regulated gene, encodes a novel cytoskeleton-associated protein that is enriched in neuronal dendrites. Neuron 14:433-445.

Martin KC, Michael D, Rose JC, Barad M, Casadio A, Zhu H, Kandel ER (1997) MAP kinase translocates into the nucleus of the presynaptic cell and is required for long-term facilitation in Aplysia. Neuron 18:899-912.
Morelli M, Fenu S, Garau L, Di Chiara G (1989) Time and dose dependence of the "priming" of the expression of dopamine receptor supersensitivity. Eur J Pharmacol 162:329-335.

Morelli M, Cozzolino A, Pinna A, Fenu S, Carta A, Di Chiara G (1993) L-dopa stimulates c-fos expression in dopamine denervated striatum by combined activation of D-1 and D-2 receptors. Brain Res 623:334-336.

Nedivi E, Hevroni D, Naot D, Israeli D, Citri Y (1993) Numerous candidate plasticity-related genes revealed by differential cDNA cloning. Nature 363:718-722.

Nguyen PV, Abel T, Kandel ER (1994) Requirement of a critical period of transcription for induction of a late phase of LTP. Science 265:1104-1107.

Nguyen TV, Kosofsky BE, Birnbaum R, Cohen BM, Hyman SE (1992) Differential expression of c-fos and zif268 in rat striatum after haloperidol, clozapine, and amphetamine. Proc Natl Acad Sci USA 89:4270-4274.

Paxinos G, Watson C (1986) The rat brain in stereotaxic coordinates. San Diego: Academic.

Robertson GS, Vincent SR, Fibiger HC (1990) Striatonigral projection neurons contain $\mathrm{D}_{1}$ dopamine receptor-activated c-fos. Brain Res 523:288-290.

Robertson GS, Vincent SR, Fibiger HC (1992) $D_{1}$ and $D_{2}$ dopamine receptors differentially regulate c-fos expression in striatonigral and striatopallidal neurons. Neuroscience 49:285-296.

Robertson HA, Peterson MR, Murphy K, Robertson GS (1989) $\mathrm{D}_{1-}$ dopamine receptor agonists selectively activate striatal c-fos independent of rotational behaviour. Brain Res 503:346-349.

Robinson TE, Kolb B (1997) Persistent structural modifications in nucleus accumbens and prefrontal cortex neurons produced by previous experience with amphetamine. J Neurosci 17:8491-8497.

Ron D, Habener JF (1992) CHOP, a novel developmentally regulated nuclear protein that dimerizes with transcription factors $\mathrm{C} / \mathrm{EBP}$ and LAP and functions as a dominant-negative inhibitor of gene transcription. Genes Dev 6:439-453.

Ruskin DN, Marshall JF (1994) Amphetamine- and cocaine-induced fos in the rat striatum depends on $\mathrm{D}_{2}$ dopamine receptor activation. Synapse 18:233-240.

Schultz W, Dayan P, Montague PR (1997) A neural substrate of prediction and reward. Science 275:1593-1599.

Shippenberg TS, Rea W (1997) Sensitization to the behavioral effects of cocaine: modulation by dynorphin and kappa-opioid receptor agonists. Pharmacol Biochem Behav 57:449-455.

Stehle JH, Foulkes NS, Molina CA, Simmonneaux V, Pevet P, SassoneCorsi P (1993) Adrenergic signals direct rhythmic expression of transcriptional repressor CREM in the pineal gland. Nature 365:314-320.

Steiner H, Gerfen CR (1993) Cocaine-induced c-fos messenger RNA is inversely related to dynorphin expression in striatum. J Neurosci 13:5066-5081.

Steiner H, Gerfen CR (1995) Dynorphin opioid inhibition of cocaineinduced, $\mathrm{D}_{1}$ dopamine receptor-mediated immediate-early gene expression in the striatum. J Comp Neurol 353:200-212.

Takano S, Fukuyama H, Fukumoto M, Hirashimizu K, Higuchi T, Takenawa J, Nakayama H, Kimura J, Fujita J (1995) Induction of CL100 protein tyrosine phosphatase following transient forebrain ischemia in the rat brain. J Cereb Blood Flow Metab 15:33-41.

Tsui CC, Copeland NG, Gilbert DJ, Jenkins NA, Barnes C, Worley PF (1996) Narp, a novel member of the pentraxin family, promotes neurite outgrowth and is dynamically regulated by neuronal activity. J Neurosci 16:2463-2478.

Yamagata K, Andreasson KI, Kaufmann WE, Barnes CA, Worley PF (1993) Expression of a mitogen-inducible cyclooxygenase in brain neurons: regulation by synaptic activity and glucocorticoids. Neuron 11:371-386

Yamagata K, Sanders LK, Kaufmann WE, Yee W, Barnes CA, Nathans D, Worley PF (1994) rheb, a growth factor- and synaptic activityregulated gene, encodes a novel Ras-related protein. J Biol Chem 269:16333-16339.

Young ST, Porrino LJ, Iadarola MJ (1991) Cocaine induces striatal c-fos-immunoreactive proteins via dopaminergic $\mathrm{D}_{1}$ receptors. Proc Natl Acad Sci USA 88:1291-1295.

Zhao S, Ooi SL, Pardee AB (1995) New primer strategy improves precision of differential display. Biotechniques 18:842-850. 